\title{
Prostitusjonsinntekter, samvittighetsforbehold og plassering av rettigheter
}

Av stipendiat Johan Vorland Wibye

Johan Vorland Wibye er stipendiat ved Det juridiske fakultet, Universitetet i Oslo.

I desember 2017 og oktober 2018 falt det to høyesterettsavgjørelser om sensitive samfunnsspørsmål - den første om erstatning for tapt prostitusjonsinntekt, den andre om samvittighetsforbehold. De rettslige sidene av disse to sakene har blitt kommentert tidligere. ${ }^{1}$ Fremfor en ny gjennomgang av innhold er formålet her å undersøke en særskilt type juridisk argumentasjon som anvendes i begge avgjørelser. Denne argumentasjonen karakteriseres av at rettigheter og plikter som tilhører ett rettssubjekt, blir brukt for å tolke rettighetene og pliktene til et annet rettssubjekt. Fokuset er med andre ord på tolkningsresonnementer som krysser linjene mellom distinkte rettssubjekter.

Den første saken, HR-2017-2352-A («Prostitusjonsinntekter»), gjaldt et søksmål fra syv kvinner om erstatning for tapt prostitusjonsinntekt. Kvinnene hadde blitt utsatt for grove ran og overfall, og de fysiske og psykiske skadene gjorde dem ute av stand til å selge seksuelle tjenester i en kort periode. Den sentrale problemstillingen var om deres tap av prostitusjonsinntekt var en erstatningsrettslig vernet interesse. Et knapt flertall (3-2) fant at interessen manglet vern. Det aktuelle resonnementet starter med en gjengivelse av straffelovgivningen, hvorved kjøp av sex er gjort straffbart, jf. straffeloven $\S 316$ første ledd bokstav a, mens salg ikke er det. Det vil si, salg av sex er lovlig. Flertallet viser imidlertid til at inntekt fra prostitusjon, selv om den ikke er ulovlig for de prostituerte, forutsetter en transaksjon hvor en av de involverte partene - kjøperen - begår en ulovlig handling. Å pålegge skadevolder å erstatte kvinnenes inntektstap vil altså, ifølge flertallet, være å anerkjenne en hypotetisk ulovlighet begått av en tredjepart. Retten kaller dette momentet «sentralt» for konklusjonen om at det ut fra sammenhengen i rettssystemet var vanskelig å bygge et rettskrav på de prostituertes tap (avsnitt 51).

Mindretallet svarer med en betimelig påminnelse om at de prostituertes rettsstilling ikke skal rammes av at andre begår lovbrudd i forbindelse med at prostitusjon foregår (avsnitt 70). Dermed løfter mindretallet frem et alminnelig metodisk utgangspunkt: Hvert rettssubjekts rettsstilling må tolkes individuelt, og rettigheter og plikter som blir tillagt den ene kan ikke uten videre transplanteres til en annen. Tolkningsutfordringen i Prostitusjonsinntekter er med andre ord så enkel som at en sex-kjøper og en prostituert er to distinkte personer. At sex-kjøpere har en straffesanksjonert plikt til å avstå fra å kjøpe sex kan derfor ikke uten videre være bestemmende for de prostituertes rett til erstatning for tapt inntekt.

Et videre poeng er at man i Prostitusjonsinntekter sto overfor et binært valg. Enten må man legge til grunn at prostituerte er underlagt et forbud mot å selge sex, eller så har de, motsetningsvis, en rett til å

\footnotetext{
${ }^{1}$ Se Birgitte Hagland, «Erstatningsvern ved personskade på saksområder hvor kvinner er typiske skadelidte», Tidsskrift for erstatningsrett, forsikringsrett og trygderett, 2018 s. 79-107; Jo Ørjasæter og Håkon Bergsjø, «Uten en tråd - Høyesterett om tapte prostitusjonsinntekter og erstatningsrettslig vern», Jussens Venner, 2018 s. 329-345; Vibeke Blaker Strand, «Nødvendig omkamp om spiralnekt», Lov og Rett, 2018 s. 325-341; Anne Kjersti Befring og Benedikte Moltumyr Høgberg, «Unødig omkamp - om religionsfrihet, diskrimineringsvern og legalitet i fastlegeordningen», Lov og Rett, 2018 s. 342-346; Stig Eidissen, «Kortvarig tap av prostitusjonsinntekter og erstatningsrettslig vern», Lov og Rett, 2019 s. 133-145.
} 
selge sex. Det finnes ikke noe tredje alternativ. Det er riktig, slik retten gjentatte ganger viser til, at samfunnet har uttrykt $\sin$ misnøye med prostitusjon. ${ }^{2}$ Men regelverket gir like fullt prostituerte en rett og frihet til å selge sex. Anerkjennelsen av ulovligheter er altså bakt direkte inn i lovens ordning - det er vanskelig å se hvordan man ellers skal kunne generere lovlig inntekt gjennom prostitusjon. Det må derfor forklares nærmere hvorfor sex-kjøperes hypotetiske, ulovlige handlinger skal være bestemmende for om de prostituerte har krav på erstatning etter tap av lovlig inntekt. Med andre ord: Hva er det ved sexkjøperes avståelsesplikt som leder til en mangel på erstatningskrav for de prostituerte? Om svaret koker ned til at avståelsesplikten er et uttrykk for samfunnets misbilligelse, og at denne misbilligelsen rammer de prostituertes erstatningsrettslige vern, er man nærmere en ren verdivurdering (av om prostituerte $b \phi r$ ha rett til erstatning) enn et resonnement som kan bære slutnings form.

Den andre saken, HR-2018-1958-A («Spiralnekt»), gjaldt oppsigelse av en fastlege etter at legen av samvittighetsgrunner hadde inngått avtale med arbeidsgiver om ikke å sette inn spiral som prevensjonsmiddel. Et samvittighetsforbehold er en rettslig anerkjent frihet for helsepersonell til å avstå fra å utføre eller delta i medisinsk behandling som strider mot deres personlige overbevisning. Fellestrekket mellom sakene er at begge inneholder slutninger fra ett rettssubjekts stilling til et annet. I Prostitusjonsinntekter er sex-kjøperes avståelsesplikt et tilsynelatende moment ved fastleggingen av de prostituertes erstatningskrav. I Spiralnekt brukes pasientrettigheter som grunnlag for å legge rettigheter til helsepersonell.

Resonnementet som vi er opptatt av i Spiralnekt, går over to avsnitt i dommen. Spørsmålet retten sto overfor var om fastlegeforskriften ${ }^{3}$ ga føringer for retten til samvittighetsforbehold. Utgangspunktet er at fastleger plikter å utføre alle tjenester som inngår i fastlegeordningen, men ifølge retten var det «grunn til å ta i betraktning» at enkelte leger ikke evner å opprettholde den nødvendige kompetansen til å utføre alle tjenester (avsnitt 50). Det forekommer derfor at pasienter blir henvist til andre, mer erfarne leger. Slik henvisning regnes ikke som et brudd på fastlegenes behandlingsplikt. Deretter skriver retten at «[s]elv om det er forskjell mellom denne situasjonen og en lege med samvittighetsforbehold (...) taler dermed gode grunner for at Helse- og omsorgsdepartementet burde ha uttrykt seg klarere i fastlegeforskriften dersom endringene i 2012 tok sikte på å forby samvittighetsforbehold ut fra den synsvinkel at det ikke var adgang til å overlate enkeltoppgaver til andre leger» (avsnitt 51).

Selv om retten ordlegger seg forsiktig, er realiteten her at det foretas en form for analogisk slutning, fra at henvisninger er tillatt, til om samvittighetsforbehold skal være tillatt. Ved første øyekast virker analogien naturlig. Som retten er inne på fører begge situasjoner til samme utfall. Én lege blir fritatt fra behandlingsplikt, og en annen lege overtar oppgaven. Retten tar også forbehold om at det er en viss forskjell mellom tilfellene. Påstanden i denne kommentaren er at rettens forbehold er utilstrekkelig. De to tilfellene er så ulike at det er lite, om noe, rom for analogiske slutninger. Grunnlaget for denne påstanden er som følger: For at en analogi skal fungere, må det være noe ved fordelingen av rettsposisjoner i de to tilfellene som ligner. Det er riktig at leger både ved henvisning og forbehold vil bli fritatt fra behandlingsplikt, men det er en avgjørende forskjell mellom rettighetene som begrunner fritaket. Samvittighetsforbehold er, etter sin art, ment å ivareta helsepersonells krav om å ikke bli pålagt oppgaver de har reservasjoner mot. Henvisninger, derimot, skjer ikke for å sikre helsepersonells rettigheter, men for å ivareta pasienters krav på best mulig behandling. Utfordringen med analogien er altså at den bruker helsevesenets ivaretakelse av pasientrettigheter som et argument for å tillegge helsepersonell rettigheter.

Påstanden om at analogien svikter kan utdypes nærmere ved å drøfte tre potensielle motargumenter. Det første alternativet er å hevde at analogien ikke bare er basert på en overflatelikhet mellom tilfellene, men at den også beror på en fra-det-mer-til-det-mindre-betraktning: Hvis vi aksepterer at leger som

\footnotetext{
${ }^{2}$ Dette er til dels av hensyn til de prostituerte selv. Begge fraksjoner gjengir forarbeidenes uttalelse om at prostituerte «har krav på vår solidaritet», jf. Innst. O. nr. 3 (2008-2009) s. 5-6. Gitt at prostitusjon er en vedvarende samfunnsutfordring, og at lignende overfall kan skje igjen, har samfunnets misbilligelse i dette tilfellet dessverre rammet nettopp de personene hvis interesser misbilligelsen skal være motivert av.

${ }^{3}$ Forskrift 29. august 2012 nr. 842.
} 
mangler kompetanse, får fritak, hvorfor skal vi ikke da akseptere at samvittighetsfulle leger får fritak ${ }^{4}$ Problemet med denne tilnærmingen er, igjen, at de to fritaksgrunnlagene er forskjellige. Manglende kompetanse leder til fritak fordi man ikke vil risikere å skade pasienter, mens samvittighetsforbehold leder til fritak fordi man vil ivareta legens samvittighet. Et videre problem er at utsagnet «leger som mangler kompetanse, får fritak» glatter over en forskjell i legers rettsstilling. For hvilke slutninger trekker vi normalt av at en person ikke er i stand til å utføre en pålagt plikt? Svaret er sjelden at personen får et avståelseskrav, og denne intuisjonen er bekreftet her. Slik det fremgår av Høyesteretts votum, kan en henvisende lege bli pålagt å erverve de nødvendige ferdighetene til å utføre behandlingen selv (avsnitt 50). Henvisning leder altså til et praktisk fritak, men den henvisende legen kan ikke kreve at pasienten blir overført. Dette til forskjell fra fritak som følge av samvittighetsforbehold, hvor pasienten nødvendigvis må bli overført til en annen lege hvis retten skal være oppfylt.

Alternativ to for å redde analogien er å hevde at henvisningspraksisen er forankret i både pasientens og legens rettigheter. Ved å henvise til en annen unngår legen tross alt påkjenningen av å måtte utføre inngrep hun har liten erfaring med, og hun unngår risikoen for at hennes uerfarenhet skader pasienten. Dette motargumentet er imidlertid også utsatt, fra flere hold. For det første er det tale om ulike interessetyper. Den henvisende legen ønsker å unngå å skade andre, mens legen som tar forbehold ønsker å ivareta sin egen samvittighet. For det andre kan leger pålegges å erverve kompetansen som trengs for å utføre inngrepet selv; sammenhengen i regelverket taler altså for at henvisning skjer for å ta vare på pasienten, og ikke for å ta vare på legen. For det tredje, og viktigst, er analogien kun treffende når man står overfor et inngrep som er så teknisk krevende at dets utførelse vil innebære en påkjenning for legen. Det forekommer imidlertid også at leger ønsker å ta samvittighetsforbehold mot enkle oppgaver, som å skrive ut resept på prevensjonsmidler. Da er det vanskelig å bruke legers rett til å unngå påkjenning som et analogisk argument for at leger har rett til fritak. For det fjerde er det ingen inngrep som er helt risikofrie. Hvis et inngrep er krevende nok til at det er grunnlag for henvisning, så kan det være at selv den erfarne legen vil komme til å oppleve en påkjenning. Motargumentets premiss, om at henvisning reduserer påkjenningen for leger, kan altså ikke garanteres i alle tilfeller.

Alternativ tre for å redde analogien er å argumentere for at både henvisning og samvittighetsforbehold skjer i konteksten av et trepartsforhold mellom pasienter, helsepersonell og myndighetene, og at relasjonene mellom dem er mer kompliserte enn hva som uttrykkes gjennom utsagn om at «pasienter har krav på behandling» og «leger har rett til fritak». Samvittighetsforbehold ville imidlertid ikke være et så betent etisk spørsmål om det var tilstrekkelig for myndigheter å legge til rette for at pasienter får behandling av en hvilken som helst lege. Argumentene mot samvittighetsforbehold aktualiseres nettopp der en pasient vil ha behandling av en spesifikk lege. Det gir derfor mening å drøfte analogien i konteksten av et topartsforhold mellom pasienter og helsepersonell.

Denne kommentaren har fokusert på en spesifikk type rettslig argumentasjon, og det er mange nyanser ved både Prostitusjonsinntekt og Spiralnekt som derfor ikke har blitt berørt. Det er særlig rom for å problematisere om de omtalte resonnementene var avgjørende for sakenes utfall. Uavhengig av hvordan slike spørsmål besvares, er det likevel en verdi i å synliggjøre tolkningsspørsmålene som oppstår når det trekkes linjer mellom rettsstillingene til ulike rettssubjekter. Til dette er sakene godt egnede. De illustrerer begge betydningen av å føre et tolkningsresonnement som er bevisst på hvor rettigheter og plikter er plassert.

\footnotetext{
${ }^{4}$ Takk til Benedikte M. Høgberg for å ha gjort meg oppmerksom på denne innvendingen.
} 